\title{
Population Resilience of Small Mammals. Why it is Important and What it Depends On?
}

\author{
Nikolay A. Shchipanov, https://orcid.org/0000-0002-8800-8837; shchipa@mail.ru \\ A. N. Severtsov Institute of Ecology and Evolution, Russian Academy of Sciences \\ 33 Leninsky Prosp., Moscow 119071, Russia
}

Received 22 June 2019, revised 18 July 2019, accepted 24 July 2019

\begin{abstract}
Shchipanov N. A. Population Resilience of Small Mammals. Why it is Important and What it Depends On? Povolzhskiy Journal of Ecology, 2019, no. 4, pp. 503 - 523. DOI: https://doi.org/10.35885/16847318-2019-4-503-523
\end{abstract}

This article is an open access article distributed under the terms and conditions of the Creative Commons Attribution 4.0 License

Small mammals are an active component of ecosystems that supports energy and matter flows and they are responsible for both construction of and maintaining their habitat. Such activity is vital for human prosperity, as it supports the chemical and physical quality of the environment where the human is adapted as a biological species. The contemporary human activity has resulted in destruction of a number of natural habitats and, as a consequence, in drastic changes in the species abundance. Some species have become so abundant that pose problems for human health, agriculture, and industries. Some formerly common and even pest small mammals, on the contrary, have reduced in distribution and numbers and now fall in the category of vulnerable species. In both cases, ecologically-based management of populations is required to maintain an optimal abundance of various species. Effective ecologically-based management of populations could be based on the basic principles of population ecology. It implies our understanding of both external and internal factors affecting the population abundance. Here, I review some fundamental principles which could be applied to operational management of populations. Also, I focus on some specifics of population reactions which have been elaborated in the Russian ecological school. Based on the well-known principles of supporting the numbers of populations, I propose a classification of species in terms of their ability to provide and change the type of functions in local populations. My classification allows distinguishing three groups of species with predictable resilience of population. Fitted to various environmental instabilities, the species of these groups require different conservation tactics.

Keywords: small mammals, ecologically-based management, population abundance, control and recovery functions, types of functional structure.

DOI: https://doi.org/10.35885/1684-7318-2019-4-503-523

Pure and applied science differ mainly in aims, not methods. Dennis H. Chitty

\section{INTRODUCTION}

A portrait of the object. Small mammals, a non-taxonomic category of species, include diverse mammals of two subclasses and 14 orders with a body length of usually less than $30 \mathrm{~cm}$ and a body weight less than $5 \mathrm{~kg}$ and cover about $90 \%$ of all living mam- 


\section{N. A. Shchipanov}

mals - that is, most of terrestrial mammalian species (Merritt, 2010). The distinguishing of this category of mammals is based on the similarity of a number of traits in the ecology of the species, which is principally attributed to their small sizes (Fleming, 1979). Indeed, scaling is a chief factor which affected morphology, physiology, and life history of a species (Schmidt-Nielsen, 1984). There are a number of advantages and disadvantages of a small size that shaped the course of the evolution and led to the specificity of their ecology (rev. Merritt, 2010).

The general biological principle is the increasing of metabolic rate with diminishing in size (Schmidt-Nielson, 1984). Almost all life history traits of small mammals resulted from their high metabolic rate. These warm-blooded animals have unprofitable surface area-to-volume ratio which enhances convective heat losses. Living near the soil surface, where fluctuations of ambient temperature are reduced, is important from perspective of economy of heat losses.

Small size promotes rather concealment than fleeing from predators; hence, small mammals either use natural or construct their own shelters. To avoid the predation of avian predators, many small mammals either inhabit at the ground strata, where they can easily hide themselves in the soil litter, or dwell in subterranean environments. As a result, the majority of the species is fitted to digging and can make more or less complex burrows and produce complex tunnel systems.

Because of their small size, small mammals are limited in their mobility and could survive to maturation in habitats with rather good food supply. Also, due to the high metabolic rate, they can travel only in areas with a sufficient amount of food resources that can cover their food needs; so, the species are limited in their ability to a nomadic way of life. This creates conflicting requirements for the survival of the population. On the one hand, small mammals should minimize their dispersal activity. On the other hand, being sensitive to fluctuations in habitat quality, local populations are at high risk of unpredictable extinction in almost any habitat and must have some stock of nonresident animals in order to restore the lost population if necessary. As a result, prosperity of a species is resulted from optimal balance of non-resident and resident individuals. Due to the limited ability to travel, the distances between individuals in the local populations can not be too much. Therefore, small mammals commonly face trade-off between high local density and risk of over-exploitation of vital resources.

High metabolic rate results in short life spans. Commonly, small mammal species lives several years, and in many species, the lifespan is less than two years. So, the high rate of population turnover is a trait of population biology of small mammals. Living in the fine-scale habitats, small mammals could find a variety of environmental conditions. Due to the rapid turnover of populations, the species were able to gain genetic adaptations to different environments in a relatively short time. As a result, we can observe a wide variety of distinct species that can occupy a wide variety of ecological niches. It should be emphasized that adaptations could touch both morphology and life strategy of species.

It is not surprising that small mammals have acquired great importance in the human's life. There are two opposite sides of their significance. When the species are very abundant, they could be harmful and regarded as pests. The same species can play a key 
role in natural ecosystems, thereby supporting the environment in which humans, as a biological species, are adapted. Thus, we ourselves face trade-off between control and conservation of a species. However, sometimes, the practical results of both pest control and conservation of vulnerable species are far from desired. A variety of attempts to constrain abundance of pest species, which has been going on for more than a century with using highly toxic agents and/or other sophisticated control methods, have not met the cardinal success (Singleton et al., 1999). Also, conservation measures have not yet led to the success in conservation of a number of vulnerable species (Pucek, 1989; Koshev, 2008; Shekarova, 2010; Surov et al., 2016).

Regarding pest control, Singleton et al. (1999) noted that the lack of progress is due to "too little research effort to understand the biology, behavior and habitat use of the species we are attempting to manage". The authors proposed the concept of "ecologically based pest management", which implies that "research on the basic biology and ecology of rodent pests" should "provide management strategies" (Singleton et al., 1999, p. 17). Obviously, the similar approach is relevant in the conservation practice, as well.

The idea of this review is to discuss some known approaches which could be useful for understanding the principles of ecologically based management of small mammals.

\section{BETWEEN PESTS AND VULNERABLE SPECIES}

Until the end of the last century, there was no particular concern for small mammals. However, a first review of the status of small rodents showed that some species that were abundant and even perceived as pests either became scarce or are drastically reducing their populations (Lidicker, 1989). Not only exotic rodents and animals with narrow inhabited ranges were considered vulnerable. Such common and recently abundant species as the European souslik, the root vole, the common hamster, and even the black rat were noted among the top ten of the vulnerable rodent species of Europe (Pucek 1989). About 40\% of known rodent species were included in the Red Book in categories of threat at the area of the former Soviet Union (Orlov, 1989). Population reduction due to pest control programs is so severe that some of formerly abundant species have been classified within the threatened category (Shilova, $2011 \mathrm{~b}$; Delibes-Mateos et al., 2011). As for example, the European rabbit lost near $70 \%$ of its population from 1973 to 1993 (Virgós et al., 2007). A trend to decreasing of populations has been noted to formerly abundant pest species - the speckled ground squirrel (Shilova et al., 2010; Shilova, 2011 a), the little ground squirrel (Shilova, Tchabovsky, 2009, Shilova, $2011 a$ ), the midday gerbil (Tchabovsky et al., 2019), and the common hamster (Surov et al., 2016) -and we have no sufficient data to estimate trend in a number of species that were recently abundant and now either have become scarce or vanished from some areas.

It is noteworthy that population dynamics of such famous species, as for example, the yellow steppe lemming, remain poorly studied. The species was common in Caspian and Kazakhstan deserts and semi-deserts at the end of the XIX century, but later, the range has drastically shrunk. The species still stayed abundant in the beginning of 20th century - later, it was almost extinct (Sokolov, 1977), -and was found again in Kazakhstan in the late 60th (Gromov, Erbaeva, 1995), and increased in numbers in 90th; in 2005, again, only several small populations were found, and we have no data for the later 


\section{N. A. Shchipanov}

period of time (Batsaikhan et al., 2019). The problem of the lack of monitoring of small mammalian populations is that the response to changes in the environment caused by humans can be delayed and is a non-linear process with a threshold value. The problem of the lack of monitoring of small mammalian populations is that the response to changes in the environment caused by humans can be delayed and is a non-linear process with a threshold value. Such reaction was found in a small mammal community in Kalmyk semi-desert, where the small souslik and the midday gerbil, formerly the key species, abruptly and sustainably fell in numbers (Shilova, $2011 a$; Tchabovsky et al., 2016).

W. Z. Lidiker (1989) has noted that rodents (and I could add that this is applicable to small mammals in general) are not such a charismatic species for "the public and politicians" as "pandas, tigers and gorillas" (p. iv). Small mammals are usually perceived as unattractive, annoying, and commonly harmful animals. What's more, the negative role of small mammals in industrial objects and agriculture, damage to food resources, and maintenance and distribution of zoonotic infections is well known (Singleton et al., 1999, 2010; Meerburg et al., 2009). Then, why should we be concerned with small mammals' conservation? Following Lidiker (1989), “... we need to launch a massive educational campaign directed not only at explaining the importance and diversity of rodents in biotic communities everywhere, but also at improving their image as necessary and desirable co-inhabitants of this planet" (p. iii-iv).

It should be reminded that E. Haeckel, who was a strong apologist of Darwin's theory, coined the term "ecology" to define scientific understanding of environment in which natural selection is proceeding (Haeckel, 1869). It implies understanding of interactions both within and between biological species and their interactions with biotic and abiotic environments. There are two key words in his definition: the "selection" and the "interactions". Being a result of long evolution, the species can persist when they are fitted to their environment. It means that they are fitted to interactions with a community of surrounded species - i.e., to available fluxes of energy and matter and to chemical, physical, and climatic characteristics of their environments. All these environmental features result from the activity of a complex of interacting taxa inhabiting a given area. First, those are primary production of organic matter and accumulation of chemical elements that are favorable for life. As result of this activity, chemical composition of the surface stratum of Earth is drastically different from composition of elements in Earth in total. A thin layer of surface that is chemically different from Earth as a whole was called by V. I. Vernadsky $(1965,1967)$ the "biosphere", because in this layer, the composition of chemicals is the result of the activity of living matter. Not only chemical environment but physical features of environment, as well, including local climatic features, are dependent on activity of communities of animal, plant, and microbial species (Sukachev, 1964). Being a biological species, humans are fitted to the current status of the planet environments. Therefore, our survival on this planet is dependent upon the fluxes of matter and energy supported by a variety of current taxa.

Merely to their abundance and high metabolic rate, the small mammals play a significant role in these fluxes. In particular, these animals affect habitat quality. The physical structure of the habitat is resulted from "physical engineering" (Jones et al., 1994, 1997). The physical construction of habitat is a result of the routine activity of the spe- 
cies. Jones et al. distinguished two big groups of engineers. Autogenic engineers change the environment by their own physical structures. Such ones are chiefly plants - as for example, the shed limbs of trees that modulate microclimate and microhabitat for other organisms on the forest floor. More complex allogenic engineers transform living or abiotic materials from one state to another by mechanical or other means. This is a case of the small mammals. The simplest example is digging of tunnels. In temperate forests of European Russia, the tunnel net makes about $70 \mathrm{~km}$ of summarized length per 1 ha and occupies 25\% of an area in projection (Bykov, 2005). This huge construction is not only a new available habitat for a great number of animal species but also a significant factor which provides for humidity regimen and aeration of soil and hence influences vegetation at an area. In addition to the direct influence of the species on the physical characteristics of habitat, it can mediate effects as a result of "biotic engineering" (Dickman, 1999). This implies dispersing of seeds and spores of some species by another taxa. This is, for example, the dispersion of fungal spores by small mammals on fur, including fungal spores that decompose cellulose (Shchipanov et al., 2003, 2006). As result, decomposing of tree waste is accelerating and the rate of fluxes of matter in ecosystem enhances. There are a number of other ways of interaction of biological species with their habitats.

The system of interacting species and their abiotic environment is called "Biogeocenosis" (Sukachev, 1964). Biogeocenosis is operating at a scale of "population" of species that compose the biotic fragment, the "Biocenosis". Abiotic fragment was called the "Ecotop". The latter involves climate and soil. Sukachev (1964) emphasized that features of all the fragments of biogeocenosis are mutually dependent. As for example, different plants have different color of leaves, thus the different albedo. Hence, changes of plant composition inevitably cause changes in amount of heat accumulated and consequently contribute to changes in local climate. Also, it should be mentioned the transpiration and shadowing of ground strata - hence, changes in ambient temperature, humidity, soil quality, etc. In general, one may say that biogeocenosis creates its own specific environment and reduces random oscillation of environmental characteristic due to activity of biotic components. Changes in composition of species will cause changes in buffer property of biogeocenosis and thus lead to deviation of habitat quality from one to which a species has been adapted in course of its evolution. So, welfare of biogeocenosis depends upon an adequate population density of the species composing biocenosis.

As it was mentioned above, small mammals are chiefly related to the soil surface; hence, their activity results to maintenance of the quality of the soil specific to a habitat. An impressive example of effects of digging activity of pocket gophers on plantation and diversity of animal species was given in C. R. Dickman's (1999) review of rodentecosystem relationships. Being fitted in various ecological niches, different species produce specific burrows. Following changes in the abundance of species, both the density and the quality of the network of tunnels change significantly (Surkova et al., 2019). In short, in natural ecosystems, these small animals do a great job for human prosperity.

Depending on the context of human activity in the territory and its own population density, the species can be considered as a pest or as a key species that provides significant ecosystem services (Dickman, 2010; Delibes-Mateos et al., 2011). The conflict with 


\section{N. A. Shchipanov}

the small mammals took start since men came to the areas inhabited by small mammals. Men-made transformation of habitats created new conditions which became more favorable for some species and unfavorable for other ones. This led to changes in species abundance, and a number of small mammals became pests due to their extremely high numbers. Under the control programs, some of these species change their category and now classified as vulnerable species. The way from a worker to pest and then to a vulnerable species is a usual trajectory for many small mammals. So, nowadays, looking for compromise between control and conservation is an urgent task (Dickman, 2010; Delibes-Mateos et al., 2011; Shilova, $2011 b$ ).

\section{TOWARDS THE OBJECT FOR MANAGEMENT}

The population density of a species is the key issue in the management. We should clearly understand 1) what density of local population of a certain species is optimal in a certain habitat, 2) what processes affect abundance of a species, and 3) at what a scale should we apply our forces to have a sustainable effect. There are some approaches in Russian ecological school which were not popular in the world science and which are unfortunately almost forgotten in Russia. Here, I want to focus on some studies which could contribute to ecologically based management.

The Russian ecological school considered "population" as a biological system which possesses features specific to this superorganismic level of integration of living matter. According to S. S. Shvarts (1960), not interaction of individuals with their habitats but the interaction of "populations" and adaptation of a species at this level should be in the focus of ecological studies. An individual animal in "population" was considered, as an analog, a cell in an organism. Demographic and genetic processes provide for maintenance of population density in the "population" as in the integrated system. This system could be subdivided in smaller entities: "micropopulations" in Shvarts terminology.

Another significant landmark in understanding of population specifics is I. A. Shilov's $(1967,1977)$ concept of "population homeostasis". He considered "population" as a "cybernetic system" where feedback provides the maintenance of optimal population density. The upper limit is due to the finiteness of available resources with unlimited population growth. If the increasing of population in numbers is not limited by any external factor, a population will inevitably reach the point of crisis. As result of overexploitation, the availability of a vital resource will fall below the value which permits survival of individuals of a species and hence will cause a collapse of "population". If the population is too diffuse, the facility to find a sexual partner is limited. This again leads to a collapse of the population. So, to persist in a habitat, a "population" should support its density at some safe level. According to I. A. Shilov, this is as important for population as homeostasis of internal environment for organisms. The key points of the concept were: 1) perception of its own abundance is mediated by "spatial-ethological" speciesspecific structure; 2) self-regulation is based on feedback mediated by physiological (pituitary-adrenal) response of an organism; and 3) species-specific spatial-ethological structure is provided by the diversity of individuals in the population. Note the latter was found to be a substantial factor for establishing residual populations under pest control 
(Shilova, 1993). Animals in a heterogeneous population have different reactions to bait and different resistance to poisons. Those animals who either were resistant to toxic agents or shunned poisoned baits survived. After the breeding cycle, the selected genotypes are crossed, and sensitive animals reappear.

It is important that according to I. A. Shilov's concept, the self-regulation is available only in resident population with stable "spatial-ethological" pattern. The animals are not able to count and can perceive only the saturation of their local groups; that is when an individual meet a familiar neighbor at a known corner of its home range, an animal understands that the area is saturated. Indeed, reproduction of house mice under saturation has stopped in confined colonies (Crowcroft, Rowe, 1957). Population growth renewed after disturbances of mice colonies (Petrusewicz, 1960, 1963). The reaction on saturation of a colony is realized as the endocrine regulation of reproduction rate mediated by the aggressive behavior (Christian, Davis, 1964). However, it should be noted that not all the small mammals, not every time and not everywhere, show this selfregulation patterns (Stearns, 1977, 1992).

The scale on which a "population" operates is arguable. S. S. Shvarts (1967) considered "population" as elementary unit which provided for persistence and microevolution in a habitat. N. P. Naumov (1963) suggested hierarchical system of populations referred to different geographic scales, from the lowest (the elementary), to the medium (the ecological), and the highest (the geographic "population"). The elementary population is not a sustainable unit, and its persistence is supported by immigration from neighbor elementary populations. This idea is rather akin to R. Levins's (1969, 1970) "metapopulation", which was further developed in I. Hanski's (1999) metapoulation theory and to Lidicker's (1985) population structuring. However, Naumov's concept has an important detail which was not so well elaborated. He proposed the idea of a "signal biological field" (Naumov, 1973), which provides relevant information about the location of animals in the area and the non-genetic transition of this information from generation to generation. There are two sorts of signals. The long-term signals include burrows, tunnels, pathways and other various long-living marks, and there are the shortterm signals, such as, acoustic signaling, visual demonstrations, etc. The latter provides with information about current status of population, while the former transmits the information about spatial structure of population to the subsequent generations. As result, for one hand, the "population" shapes its habitat; for another hand, the spatial structure of the "population" has a historic component. It means that the dispersal is historically canalized, and there are some areas between which the immigration is more likely, irrespective of currently observed outward habitat mosaic.

The latter idea is important to highlight a unit for practical operations. Regarded function of population subunits, V. N. Beklemishev (1960) proposed idea of "independent population". The independent population is a unit of species where the numbers depend on the breading-mortality balance solely, while in subpopulation units, it resulted from immigration-emigration balance, as well. The idea, in particular, was based on pest control data. The impact had a long-term effect when the control measures covered the entire independent population. When, under the same effort, the treatment covered parts of different independent populations, the only short-term effect could be achieved. Tak- 


\section{N. A. Shchipanov}

ing into account Naumov's signal field, one may conclude that distinguishing of such independent populations in small mammals could not be based on the considering of any external signs without studying actual structure of connectivity of local populations.

An importance of understanding population substructuring for understanding population dynamics was emphasized in Lidicker's (1985) publication. Obviously, small local populations are under high risk of extinction, and a unit for conservation should involve some number of connected local populations. However, taking into consideration historicity of arrangement of connections between those population subunits in space, one may conclude that there are cases when distinguishing of such units required the study of actual connections between subpopulations. According to Beklemishev (1960), if the applied measures will cover dependent subunits of different independent populations, the sustainable effect will not been achieved irrespectively of the size and the habitat structure of the terrain to which those measures were applied.

\section{SURVIVAL}

Viability of populations depends on both demographic and genetic patterns. The number of effectively interacting individuals should be sufficient to avoid demographic and genetic traps under occasional fluctuations of population density. The lower population limit, "minimum viable population" (MVP), was coined as "the smallest number of individuals required for an isolated population to persist (at some predefined "high" probability) for some "long" time into the future" (Shaffer, 1981). MVP should provide for survival under: 1) Demographic uncertainty. It could be caused by random demographic events, ex. survival of elder individuals with low reproductive potential, sex disproportion, etc. 2) Environmental uncertainty. It could be caused by random oscillations of environment, ex. weather, increased number of competitors, predators, etc. 3) Genetic uncertainty. It could be caused by random genetic processes, ex. genetic load, genetic drift, inbreeding, etc. 4) Catastrophic uncertainty. It could be caused by periodic disasters which are unpredictable for population, such as fires, flooding, drought, etc.

Survival of a population increases when local populations are interlinked. Population which is composed of interlinked local populations, "population of populations," was called "metapopulation" by R. Levins (1969). Survival of metapopulations was carefully analyzed by I. Hanski (2005). Each local population in the metapopulation is under the risk of extinction, and its persistence is supporting by immigration from connected local populations. Metapopulation normally occupies heterogeneous environment, i.e., an area with different habitats. Local populations inhabited in different habitats can not be simultaneously impacted by one factor. As a result, survived populations became a source for the suffered units. The transient habitats where the animals can not establish residence and reproduce are no less important for survival of metapopulation as habitats in which reproducing population can live (Hanski, 2011).

It was proposed to distinguish between populations of sinks, that are dependent, and populations of sources, that produce dispersing animals needed to restore the sink population (Lidicker, 1975). Note, sink populations could have greater population density than the source population. "About $90 \%$ of population might occur in one habitat. On the basis of the relative abundance and breeding status of individuals in this habitat, one 
might conclude that destruction of a nearby alternative habitat would have relatively little impact on the population. "However, if the former habitat were a sink and the alternative a source, destruction of a relatively small habitat could lead to local population extinction" (Pulliam, 1988, p. 659).

Two interrelated types of processes should be discussed: reproduction among the local population and dispersal. According to P. Turchin (2001) “... three foundational principles of population dynamics are conceptually very similar to laws in certain fields of physics". Those are 1) exponential growth of population, 2) self-limitation of reproduction and 3) consumer-resource oscillations. "In them the exponential law is a direct analogue of the law of inertia in that it provides the starting point for a mathematical description of dynamics of population systems" (Turchin, 2001). Whereas the two former laws describe the principle of increasing of the number of individuals in a population, the latter law describes the interaction of a species with a renewable resource or with a factor which is dependent on the abundance of a focal species. The equations do not take into account processes of immigration-emigration. However, these principles are very important for understanding the intrinsic population factors that influence the dispersal.

In species which have no self-limitation mechanisms regulating reproduction, the local density of population could be constrained either by externally caused mortality or by emigration. When such a species lives in a favorable environment and its ability to emigrate is limited, overpopulation becomes possible. If dispersal is not limited, overpopulation can be avoided by emigration, but there is no possibility for immigration. A lack of immigration enhances probability of inbreeding, hence of the genetic load manifestation. In both cases, population may collapse. So, some level of disturbances is required for sustainable survival of such species.

Self-limitation of reproduction prevents overpopulation. It may seem that superstable environment is favorable for such a species. However, in super-stable habitat, local population could fall in a demographic trap. When local population is saturated, the rate of renewing of population is minimal, hence old individuals with lost reproductive capacity may prevail in demographic pattern, and the latter leads to population collapse. Also, population is under jeopardy to fall in genetic trap. On the one hand, the saturated local population is limited in their ability to produce extra individuals, and this limits the level of emigration. Therefore, such population can not function as a source. On another hand, a facility of effective immigration into this population is low. As a result, the likelihood of fixation of deleterious alleles increases.

According to Shilov's population homeostasis, the reproduction can be selfregulated only under stabilized "spatial-ecological" structure. Until the structuring of population is not complete, the reproduction is not dependent on population density. So, some disturbance of local population is required for maintenance of the whole system of interacting local populations of species with self-regulation of reproduction rate.

Population sub-structuring plays a significant role in population dynamics (Lidicker, 1985) and genetic effects (Hanski, 2011). The risk of population extinction due to fixation of new deleterious mutations is substantial, even in relatively large randomly mating population (Lande, 1994). In cases where local populations, on the one 


\section{N. A. Shchipanov}

hand, are sufficiently isolated to provide separate genetic processes, and on the other hand, are sufficiently connected to maintain the integrity of the entire system, the risk of allele fixation is significantly reduced (Altukhov, 2003).

The key importance in the models of subdivided populations belongs to the dispersal (Lidicker, 1978). Generally, dispersal could be regarded as 1) saturation dispersal, when dispersal is resulted from residual reproduction in saturated group, and 2) presaturation dispersal, when dispersal provides for preventing the overcrowding of a local population (Lidicker, 1975). The type of dispersal is resulted from different social patterns of local population and is characterized by different demographic patterns of nonresident fraction of populations. Under presaturation dispersal, the demographic pattern of dispersal is unbiased. It includes animals with high reproductive potential. In situations when the risk of extinction of small local populations is high, the presaturation dispersal is critical for survival of the whole system of interlinked local populations (Lidicker, 1985). Saturation dispersal pattern is biased; it involves chiefly young immature individuals and mature males. Such pattern may provide for maintenance of genetic heterogeneity; however, it is not sufficient for recolonization.

The stochasticity of metapopulation in time and space significantly reduces risk of fixation of deleterious alleles. A substantial fluctuation of population density, either cyclic or non-cyclic, is a characteristic feature of many species of small mammals living in boreal and temperate habitats. The population dynamics could be borne by a variety of external and proximal population factors. In particular, the fluctuated dynamics could result from the delayed reaction on a resource or predator abundance, as Lotka-Volterra equations predict (Barryman, 2002). The predator-prey interactions are regarded as the principal, not always, cause of cyclic population dynamics (Hanski et al., 2001; Gilg et al., 2003).

The genetic cause of population cycle today is not a widely discussing issue. However, genetic effects in fluctuated populations may become the most significant factor of viability of population. D. Chitty $(1958,1960,1967)$ hypothesized that periodic fluctuation of population density is driven by fluctuation of proportion of docile and aggressive genotypes. At the phases of high density, "aggressors" prevail but, however, due to strong competition, die under peak density, while docile individuals survive. These fluctuations could be regarded as density-dependent selection of different behavioral genotypes. Although clear evidences in support of Chitty's hypothesis have not been found, it gives an idea of inherited behavior which can control population density genetically (Stenseth, 1981). In models with density-dependent changes in the proportion of different genotypes, fluctuations in population density without external factor damped over time, but even relatively rare impacts can bear a population cycle based on dynamic ratio of genotypes (Stenseth, 1978). Regarding prolonged phases of low density, R. Boonstra et al. (1998) noted that genetics of the behavioral traits is "the least likely, but still vaguely possible, explanation involves genetic differences between animals present at the low phase and those present at other phases." According to these authors, "There are few studies of the inheritance of traits that are important in spacing behavior in small mammals. Although we appreciate that these studies are difficult, they are crucial in evaluating the polymorphic behavior hypothesis" (p. 1486). 
The fluctuations of genotype frequency could be regarded also in terms of "bethedging" hypothesis. Under increased mortality of the adult individuals, the selection may favor to early maturated individuals (Stearns, 1992). The modeling of age-specific dispersal under density-dependent selection show 1) that such fluctuations are consistent with Chitty hypothesis and 2) that "whatever the mechanism that controls multi-annual population cycles in northern herbivores; it leads to major changes in the demographic structure of cycling populations" (Morris, 1984). In any of the cases, it is important that genetically based behavior is adjusted to survival of population under critically low population density in the phases of depression, and in any model, this survival is based on the enhanced dispersal of animals with high reproductive capacity.

Some recent studies forced to focus attention on the genetically controlled lifehistory traits in small mammals again. Populations and species often exhibit suites of behaviors correlated across situations called the behavioral syndromes (Sih et al., 2004). In particular, some individuals are more aggressive, whereas others are less aggressive across a range of situations and contexts. The authors wrote, "Recent studies suggest that the behavioral type of an individual, population or species can have important ecological and evolutionary implications, including major effects on species distributions, on the relative tendencies of species to be invasive or to respond well to environmental change, ..." (Sih et al., 2004, p. 372). Indeed, there are several evidences that genetically controlled behavior can contribute to level of aggressiveness. In house mice, aggressive and nonaggressive lineages have been selected from wild population (Van Oortmerssen, Sluyter, 1994). The differences in aggressiveness is related to pseudoautosomal (YPAK) and non-pseudoautosomal (UNPAR) sites of Y chromosome (Sluyter et al., 1996).

The behavioral type of an individual, a personality, can have important ecological implications, including, in particular, ability to respond to environmental change (Sih et al., 2004). Personality traits are closely related to genetically controlled neuroendocrine bases of variation in behavioral type. A substantial segment of the behavioral specifics is attributed to pace-of-life (POLS) syndrome. "Personality and metabolism, and metabolism and life history provide an intriguingly plausible path of causality that would manifest as a POLS spanning physiology, behaviour and life histories" (Réale et al., 2010, p. 4052). The aquatic vole (Arvicola amphibious) could give a splendid example. The vole exhibits inherited changes in maturation rate, aggressiveness, and stress reactivity associated with the color of fur (Evsikov et al., 1995). Black and brown are homozygous, and dark-brown is heterozygous animal. Dark-brown voles became mature younger, disperse sooner, and switch to reproduction. The proportion of differently colored individuals changed in the cause of multiannual cycle. The brown individuals predominate in the peak years, whereas the dark-brown and black voles are most frequent in the years of low population density.

\section{IS THE RESILIENCE PREDICTABLE?}

Small isolated populations are commonly at the risk of accidental extinction under uncertain catastrophic events. Even a relatively large free mating population is at risk of extinction due to fixation of deleterious alleles. Thus, the ability of periodic recolonization of devastated territories can be considered as a universal requirement ensuring the 


\section{N. A. Shchipanov}

viability of the species in the natural environment. Obviously, this ability is required in different species to varying degrees. Small mammals are fitted to variety of habitats with different favorability, dynamics, and predictability of environments, and they gain their adaptations on the different genetic basis. Unfortunately, the dynamism of the environment for a species can not been assayed a priori. A species may have some special biological adaptations, such as, for example, torpor or hibernation, complex burrows, ability to swim and dive, etc., which ensure survival of the events looking like a disaster for us.

We could evaluate the ability of a species to recover by observing the response of the species to a natural disaster; however, natural catastrophes are rare and unpredictable events. Therefore, we have a few chances to accumulate sufficient data to analyze natural capability of a species to recover local populations. However, one may involve the data obtained in field experiments in the course of pest control studies. The study of compensation mechanisms in populations of small mammals subjected to pest control measures, similar to natural disasters, allows us to reveal the fundamental principles of population survivability (Shilova, 1993). Analyzing the effect of the control with previous and following surveillance of the demographic and behavioral patterns in target populations in six small mammal taxa, Shilova and Tchabovsky (2009) have found that behavioral mechanisms, as well as physiological specifics of species, are among the major driving forces stimulating recovery. The gerbils that are more susceptible to social environments exhibited quicker recovery. Sensitivity to the social environment is not necessarily related to the communal space used. In that study, the least socially sensitive species, the midday gerbil, Meriones meridianus, could form unusual dense groups with overlapping home ranges; however, even in dense local populations, the gerbil was not sensitive to presence of neighbors (Shilova et al., 1983). Under dropped density, the midday gerbil did not manifest any changes in space use and reproduction rate. Depopulated patches in dense colonies (manual removal of animals) remained unpopulated until the next season of reproduction, and no one animal moved from neighbor area to those patches. Contrary, a solitary living species, the tamarisk gerbil, $M$. tamariscinus, rapidly recovered local populations. The key for understanding the response on the artificially caused depression in the latter species is the delayed dispersal of young females. The reproduction of those females is suppressed in presence of mothers. Following population depression, these young females can realize their reproductive potential (Shilova, Tchabovsky, 2009).

So, to understand the ability of a species to recover local population after a catastrophic event, we should take into account various aspects of the biology of species. Indeed, small mammals are so diverse in their ecology, life histories, and social interactions. Nevertheless, I suppose that there could be some generalities in their ability to population recovery.

I suggested distinguishing alternative functions of local populations, the "control" and the "recovery". The ability to procure one of the functions or both functions in population was regarded as "functional structure" (Shchipanov, 2000, 2002, 2003).

The "control" function provides for preventing of local overcrowding. This function can be realized on the basis of the physiological mechanisms of self-regulation or on the basis of the genetically fixed reproduction rate matching the regular turnover of the 
population. As a result of the "control" function, the reproduction effort is minimized; however, the dispersion rate is also minimized. Immature young animals and males predominate in the dispersal pattern. Such dispersal can not support quick recovery.

The "recovery" function provides for reproduction in excess. The function can be realized when self-regulation in disturbed colonies is turned off or due to a constant high level of reproduction, which is genetically fixed. When the function is performed, the avoidance of overcrowding in local population is resulted from emigration of extra individuals, similar to Lidicker's (1975) presaturation dispersal. Dispersal pattern is unbiased and includes mature females ready to reproduce. Such dispersal can provide rapid repopulation of depopulated areas.

The realization of one of the alternative functions in a local population can be operationally detected by the stability of the personal composition of the residents, the proportion of the non-residents in the daily catch, and the demographic pattern of dispersal (Shchipanov, 2000, 2002, 2003, 2016). The combination of species by the ability to produce local populations with the control and recovery functions gives three principal functional groups. Taking into account the mechanisms for supporting the function, the 1 st group is subdivided into two subgroups (Figure). The rate of recovery and survivability of species from those functional groups and subgroups is rather predictable (Shchipanov, 2003, 2016).

Species of the first group can produce local populations with both functions; however, species of the 1a group can change mode of functioning directly, as a response on impact, whereas $1 \mathrm{~b}$ group species change the function with a delay. The 1a species are able to do "nonspecific population adaptation", meaning that along increasing of environmental instability, the proportion of local populations with the recovery function increases (Shchipanov, 2000, 2002, 2003). The $1 \mathrm{~b}$ species manifested different rate of recovery in different phases of the population cycle. Paradoxically, the lowest recovery rate is expected at peak density. As for example, in Chukotka, in the root vole (Microtus oeconomus), depopulated area remained unpopulated during the entire warm season at the highest density of the remained local populations, and it was constantly repopulating almost with the rate of removing of the voles under relatively low population density (Shchipanov, Kasatkin, 1992).

The species of the $2^{\text {nd }}$ and $3^{\text {rd }}$ groups constantly perform only one type of function, either the recovery $\left(2^{\text {nd }}\right)$ or the control $\left(3^{\text {rd }}\right)$.

Fitted to different environmental instability, the species of these groups require different conservation tactics. The 1 a species could lose sustainability in confined superfavorable environments due to minimization of reproduction, as house mice do in confined colonies (Crowcroft, Row, 1957). This reduces the inter-population migration, hence the limitation of gene flow between different local populations. The situation could be corrected when some level of artificial disturbance is applied to a number of different populations or local groups. Even small level of disturbance could push the colony to enhance reproduction, as in the house mice in Petrusewicz's (1963) experiments.

The species of the $1 \mathrm{~b}$ are sensitive to heterogeneity of habitat structure. High local density in these species may not indicate the favorable habitat, as it was shown in mi- 


\section{N. A. Shchipanov}

crotine cyclic populations (Lidicker, 1985). If solely favorable environments are under protection, a species may lose "dispersing" genotypes, hence losing ability to recovery. If there are no favorable habitats in the protected area, the species may lose the genotypes responsible for the high local density. Hence, the species will not be able to perform its ecosystem function.

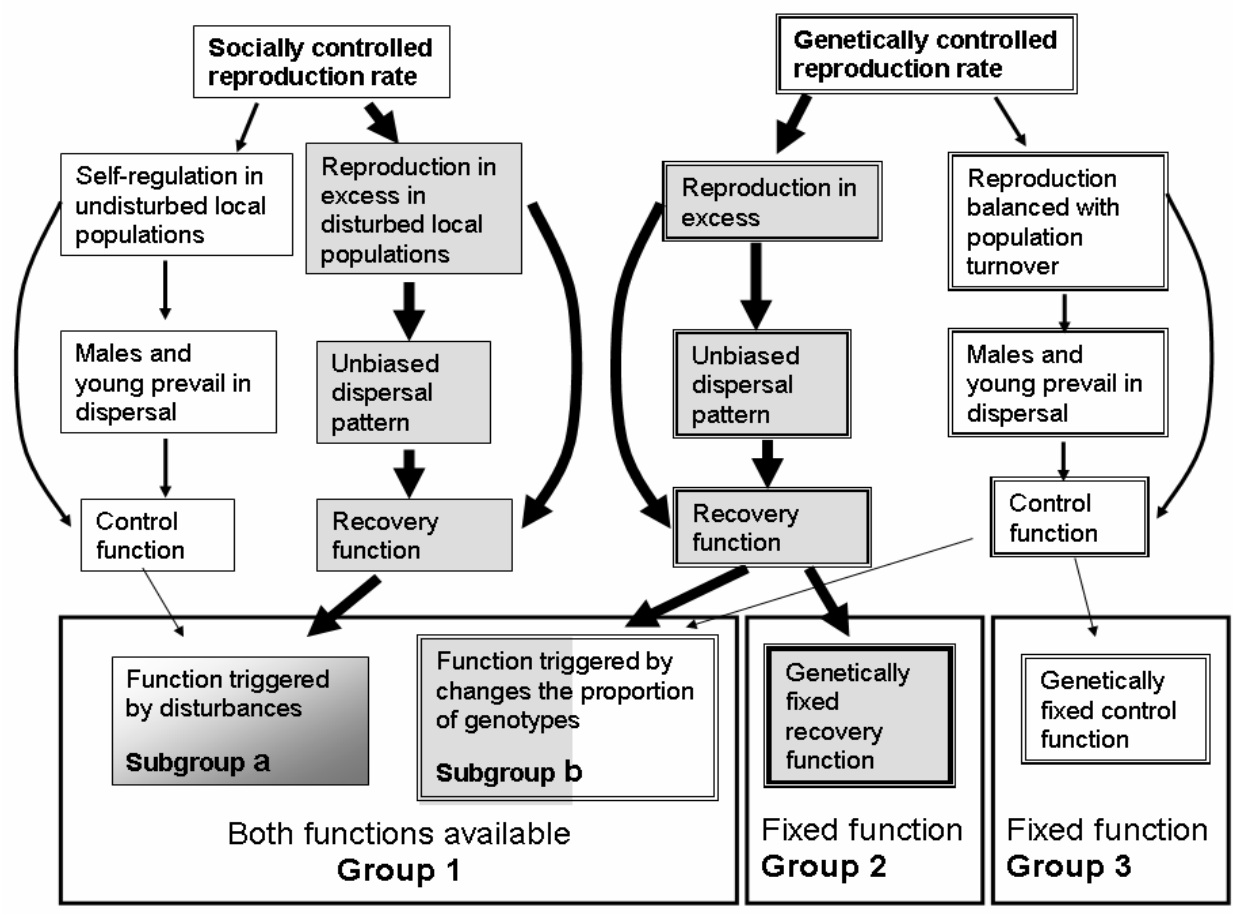

Figure. Classification of species according to functional structure of population (according to Shchipanov, 2000). Two principally different ways of regulation of reproduction rate: the socially controlled (single line frame) and genetically controlled (double lined frame) results to different ability to enhance dispersal rate and to form dispersal pattern available to perform recovery function. Group 1 is distinguished due to ability to produce local populations with both patterns but involve two different lines. Species of the "socially controlled" column make subgroup $a$. la species can change the type of functioning of local population following an impact. Species of the "genetically controlled" column produce the subgroup $b .1 \mathrm{~b}$ species can change the type of function only with a delay which is required to change proportion of genotypes. More detailed expected resilience of the species of the functional groups is discussed in Shchipanov, 2016

The species of the $2^{\text {nd }}$ group are normally scarce and scattered over vast area. Those could present in a great variety of habitats; however, they are rare or never abundant. Their survival is based on the wide dispersal. For example, the lesser shrew, Sorex minu$t u s$, could be met in a variety of habitats of boreal and temperate zone and has been 
found even in the big cities (Karaseva et al., 1999), but it is never in abundance. In forests of Central Russia, the animals are under high risk of occasional mortality, and their survival to reproduction is a random event. One may say that all the habitats are unfavorable for this species. However, the population had sustainable numbers due to permanent repopulation of all the observed area (Shchipanov et al., 2005). Apparently, no special conservation measures can be proposed for such species.

The species of the $3^{\text {rd }}$ group are normally numerous. Such species can minimize their reproductive rate due to perfect adaptations to the environment in which they live. Consequently, those species should be very susceptible to any disturbance in a habitat. Being limited in their ability to enhance reproduction, these species are sensitive to increased mortality under direct impacts. In addition, the fragmentation of favorable habitats can lead to a collapse of the population, which may be the result of an increase in the inbredness of local populations and the manifestation of gene load.

I have no good example on the latter issue; however, the situation with the midday gerbil in Kalmyk looks rather similar to this expectation. Formerly, I have referred this species to the $3^{\text {rd }}$ group due to lack of socially related reproduction rate, limited dispersal, and extremely slow recovery of even small depopulated patches (Shchipanov, 2000, 2003, 2016). The same specifics of population reaction under impacts were described in the Shilova and Tchabovsky (2009) publication. The species was abundant in desert habitats in $20^{\text {th }}$ century. In $90^{\text {th }}$, livestock numbers in Kalmyk drastically reduced. This was followed by overgrowing of the major area with tall grasses. Such grasslands are unfavorable for midday gerbil and, in particular, hampered dispersal. The gerbil remained abundant in the patches of favorable habitats until the 2002; then, it dropped twice in numbers with gradual diminishing of abundance in following ten years and is absent in captures since 2017 (Tchabovsky et al., 2016, 2019). It is noteworthy that the number of deserted habitats favorable for this species has been increasing again in the last 10 years. However, instead of increasing, the number of midday gerbils continued to decline and culminates the population collapse (Tchabovsky et al., 2019). In that publication, the authors suggested that population collapse resulted from the environmental and demographic stochasticity, which affects mainly small fragmented populations. I can note also that the delayed response and followed population collapse is more congruent with the idea of fixation of deleterious alleles in small "confined" populations. However, this is only my proposal, and the genetic aspect of the population collapse in the midday gerbil requires special study.

\section{INSTEAD OF CONCLUSION}

An abundant species may suddenly become extinct. We have a charismatic example, the passenger pigeon, Ectopistes migratorius. The bird was so abundant that it made a substantial source of food for the people of North America. The number of pigeons was estimated in a range of 3-5 billions of birds. In the mid- $19^{\text {th }}$ century, it was a special industry based on harvesting passenger pigeons. About 1.8 millions of birds were delivered in big cities by trains in 1851. Feeding flocks of the pigeon destroyed the entire crops in some farms, and the species was regarded as pest. From perspective of farming, the pigeon was described as a "perfect scourge", and special hunters were employed to 


\section{N. A. Shchipanov}

"wage warfare". The noticeable decrease was noted in 70th; first attempts of conservation were made since late 50th, but they were ineffective. The species almost vanished from wild within several decades by the mid-1890s, and in the beginning of 20th century, the pigeon was entirely extinct (Greenberg, 2014).

The history of extinction shows that there have been several decades when appropriate conservation measures could be effective. However, there was perception that population of the passenger pigeon still stays abundant. The flocks seemed no smaller until population sizes extremely reduced. There are two quotes with which I want to finish this review: "Reliance on casual observation is not likely to be a suitable monitoring strategy for many species, particularly while they are still relatively abundant". "There is a great need for the expansion of global wildlife population monitoring programs and risk assessment based on population-level symptoms" (Stanton, 2014, p. 19).

\section{Acknowledgments}

This work was carried out as part of the state assignment of Center for Information Technology and Systems "Ecology and Biodiversity of Terrestrial Communities" (No. 0109-2018-0077) and with financial support from the Russian Foundation for Basic Research (project No. 19-04-00985).

\section{REFERENCES}

Altukhov Yu. P. Genetic Processes in Populations. Third edition. Moscow, Akademkniga Publ., 2003. 431 p. (in Russian).

Barryman A. A. Do trophic interactions population cycles? In: A. A. Barryman, ed. Population Cycles: The Case for Trophic Interactions. Oxford, Oxford Univ. Press, 2002, pp. 177-188.

Batsaikhan N., Avirmed D., Tinnin, D. Eolagurus luteus. The IUCN Red List of Threatened Species, 2016, pp. e.T7782A115086020. Available at: http://dx.doi.org/10.2305/IUCN.UK.20163.RLTS.T7782A22370187.en (accessed 19 October 2019).

Beklemishev V. N. Spatial and Functional Structure of Population. Bulletin of Moscow Society of Naturalists, Biological Ser., 1960, vol. 65, no. 2, pp. 41-50 (in Russian).

Boonstra R., Krebs C. J., Stenseth N. Cr. Population Cycles in Small Mammals: the Problem of Explaining the Low Phase. Ecology, 1998, vol. 79, iss. 5, pp. 1479-1488.

Bykov A. V. Nornaia set' melkikh mlekopitaiushchikh kak biotsenoticheskaia sostavliaiushchaia pochvennogo iarusa lesnykh ekosistem [Tunnel Net of Small Mammals as Biocenotic Component of Soil Layer of Forest Ecosystems]. Thesis Diss. Dr. Sci. (Biol.). Moscow, 2005. 53 p. (in Russian).

Chitty D. Self-regulation of Numbers Through Changes in Viability. Cold Spring Harbor Symposia on Quantitative Biology, 1958, vol. 22, pp. 227-280.

Chitty D. Population Processes in the Voles and Their Relevance to General Theory. Canadian J. of Zoology, 1960, vol. 38, pp. 99-113.

Chitty D. The Natural Selection of Self-regulatory Behaviour in Animal Populations. Proceedings of the Ecological Society of Australia, 1967, vol. 2, pp. 51-78.

Christian J. J., Davis D. E. Endocrines, Behavior and Population. Science, 1964, vol. 146, pp. $1550-1560$.

Crowcroft P., Rowe F. P. The growth of confined colonies of the wild house mouse (Mus musculus L.): The effect of dispersal on female fecundity. Proceedings of the Zoological Society of London, 1957, vol. 131, pp. 359-370. 


\section{POPULATION RESILIENCE OF SMALL MAMMALS}

Delibes-Mateos M., Smith A. T., Slobodchikoff C. N., Swenson J. E. The Paradox of Keystone Species Persecuted as Pests: A Call for the Conservation of Abundant Small Mammals in Their Native Range. Biological Conservation, 2011, vol. 144, pp. 1335-1346.

Dickman A. J. Complexities of conflict: the importance of considering social factors for effectively resolving human-wildlife conflict. Animal Conservation, 2010, vol. 13, pp. 458-466.

Dickman C. R. Rodent-ecosystem relationships: a review. In: G. Singelton, L. Hinds, H. Leirs, Z. Zhang, eds. Ecologically Based Rodent Management. Canberra, Australian Centre for International Agricultural Research, 1999, pp. 113-133.

Evsikov V. I., Moshkin M. P., Potapov M. A., Gerlinskaia L. A., Nazarova G. G., Novikov E. A., Ovchinnikova L. E., Rogov V. G., Muzyka V. Yu. Genetic and evolutional aspects of population homeostasis. In: I. A. Shilov, ed. Ecology of Populations: Structure and Dynamics. Moscow, Tipografiia Rossel'khozakademii, 1995, vol. 1, pp. 63-96 (in Russian).

Fleming T. H. Life History Strategies. In: M. Stoddart, ed. Ecology of Small Mammals. London, Chapmen and Hall, 1979, pp. 1-61.

Gilg O., Hanski I., Sittler B. Cyclic Dynamics in a Simple Vertebrate Predator-prey Community. Science, 2003, vol. 302, pp. 866-867.

Greenberg J. A Feathered River Across the Sky: The Passenger Pigeon's Flight to Extinction. New York, Bloomsbury, 2014. 304 p.

Gromov I. M., Erbaeva M. A. Mammal Fauna of Russia and Adjacent Territories. Lagomorphs and Rodents. St. Petersburg, Zoologicheskii institut RAN Publ., 1995. 522 p. (in Russian).

Haeckel E. Euber Entwichclunge Gung 4. Aufgabe de Zoologie Jemaische z., 1869, vol. 5, pp. 353-370.

Hanski I. Metapopulation Ecology. Oxford, Oxford University Press, 1999. 328 p.

Hanski I. The Shrinking World: Ecological Consequences of Habitat Loss. Oldendorf, Luhe, International Ecology Institute, 2005. 307 p.

Hanski I. Habitat Loss, the Dynamics of Biodiversity, and a Perspective on Conservation. Ambio, 2011, vol. 40, iss. 3, pp. 248-255.

Hanski I., Henttonen H., Korpima E., Oksanen L., Turchin P. Small-rodent Dynamics and Predation. Ecology, 2001, vol. 82, iss. 6, pp. 1505-1520.

Jones G. G., Lawton J. H., Shachak M. Organisms as Ecosystem Engeneers. Oikos, 1994, vol. 69, pp. 373-386.

Jones G. G., Lawton J. H., Shachak M. Positive and Negative Effects of Organisms as Physical Ecosystem Engineers. Ecology, 1997, vol. 78, pp. 1946-1957.

Karaseva E. V., Telitsina A. Yu., Samoilov B. L. Mammals of Moscow in the Past and Present. In: S. A. Shilova, ed. Mlekopitayushchie Moskvy v proshlom i nastoyashchem. Moscow, Nauka Publ., 1999. 245 p. (in Russian).

Koshev Y. S. Distribution and status of the European Ground Squirrel (Spermophilus citellus) in Bulgaria. Lynx (Praha), 2008, vol. 39, iss. 2, pp. 251-261.

Lande R. Risk of Population Extinction from Fixation of New Deleterious Mutations. Evolution, 1994, vol. 48, iss. 5, pp. 1460-1469.

Levins R. Some Demographic and Genetic Consequences of Environmental Heterogeneity for Biological Control. Bulletin of the Entomological Society of America, 1969, vol. 15, pp. 237-240.

Levins R. A. Extinction. Lectures on Mathematics in the Life Sciences, 1970, no. 2, pp. 75-107.

Lidicker W. Z. Jr. The Role of Dispersal in the Demography of Small Mammals. In: F. B. Golley, K. Petrusewicz, L. Ryszkowski, eds. Small Mammals: Their Productivity and Population Dynamics. New York, Cambridge University Press, 1975, pp. 103-128.

Lidicker W. Z. Jr. Regulation of Numbers in Small Mammal Populations - Historical Reflections and a Synthesis. In: D. P. Snyder, ed. Populations of Small Mammals Under Natural Conditions. Pymatuning Symp. Ecol. 1978, vol. 5, pp. 122-141. 


\section{N. A. Shchipanov}

Lidicker W. Z., Jr. Population Structuring as a Factor in Understanding Microtine Cycles. Acta Zoologica Fennica, 1985, vol. 173, pp. 23-27.

Lidicker W. Z., Jr. Introduction. In: W. Z. Jr. Lidicker, ed. Rodents. A World Survey of Species of Conservation Concern. Occasional Papers of the IUCN Species Survival Commission (SSC), 1989, no. 4, pp. iii-iv.

Meerburg G. M., Singleton G. R., Kijlstra A. Rodent-borne Diseases and Their Risks for Public Health. Critical Reviews in Microbiology, 2009, vol. 35, pp. 221-270. DOI: https://doi.org/10.1080/10408410902989837

Merritt J. F. The Biology of Small Mammals. Baltimore, The Johns Hopkins University Press, 2010. $313 \mathrm{p}$.

Morris D. W. Rodent Population Cycles: Life History Adjustments to Age-specific Dispersal Strategies and Intrinsic Time Lags. Oecologia (Berlin), 1984, vol. 64, pp. 8-13.

Naumov N. P. Animal Ecology. Moscow, Vysshaia shkola Publ., 1963. 618 p. (in Russian).

Naumov N. P. Signal Biological Fields and Their Significance for Animals. Zhurnal obshchei biologii, 1973, vol. 34, iss. 6, pp. 808-817 (in Russian).

Orlov V. N. Rodents of Conservation Concern in the Soviet Union Region. In: W. Z. Jr. Lidicker, ed. Rodents. A World Survey of Species of Conservation Concern. Occasional Papers of the IUCN Species Survival Commission (SSC), 1989, no. 4, pp. 40-41.

Petrusewicz K. An Increase in Mice Population Inducted by Disturbance of the Population. Bulletin of the Polish Academy of Sciences, Ser. Biological Sciences, 1960, no. 8, pp. 301-304.

Petrusewicz K. Population Growth Induced by Disturbance in the Ecological Structure of the Poulation. Ekologia Polska, 1963, vol. 11, iss. 3, pp. 87-125.

Pucek Z. A. Preliminary Report on Threatened Rodents in Europe. In: W. Z. Jr. Lidicker, ed. Rodents. A World Survey of Species of Conservation Concern. Occasional Papers of the IUCN Species Survival Commission (SSC), 1989, no. 4, pp. 26-33.

Pulliam H. R. Sources, Sinks, and Population Regulation. American Naturalist, 1988, vol. 132, pp. 652-661.

Réale D., Garant D., Humphries M. M., Bergeron P., Careau V., Montiglio P.-O. Personality and the Emergence of the Pace-of-life Syndrome Concept at the Population Level. Philosophical Transactions of the Royal Society of London, Ser. B: Biological Sciences, 2010, vol. 365, pp. 4051-4063. DOI: https://doi.org/10.1098/rstb.2010.0208

Schmidt-Nielsen K. Scaling: Why is Animal Size so Important? Cambridge, Cambridge University Press, 1984. $241 \mathrm{p}$.

Shaffer M. L. Minimum Population Sizes for Species Conservation. BioScience, 1981, vol. 31, iss. 2, pp. 131-134.

Shchipanov N. A. Some Aspects of Resilience of Small Mammal Populations. Uspekhi sovremennoi biologii, 2000, no. 1, pp. 73-87 (in Russian).

Shchipanov N. A. Functional Organization of Population: an Approach to Studying of Population Survivability. Applied aspects (Small mammals as example). Zoologicheskii zhurnal, 2002, vol. 81, iss. 9, pp. 1048-1077 (in Russian).

Shchipanov N. A. Population as a Unit of Species Existence: Small Mammals. Entomological Review, 2003, vol. 83, pp. 142-160.

Shchipanov N. A. Population Structure and Species Diversity of Small Mammals. Aspects of Biodiversity. Archives of Zoological Museum of Moscow State University. Moscow, KMK Scientific Press Ltd., 2016, pp. 478-513 (in Russian).

Shchipanov N. A., Kasatkin M. V. Annual changes in spatial population structure of the root vole in tundra. Bulletin of Moscow Society of Naturalists, Biological Ser., 1992, vol. 97, no. 4, pp. 14-27 (in Russian). 


\section{POPULATION RESILIENCE OF SMALL MAMMALS}

Shchipanov N. A., Aleksandrov D. Yu., Aleksandrova A. V. Small Mammals Disperse Micromycete Spores. Doklady Biological Sciences, 2003, vol. 390, pp. 225-230.

Shchipanov N. A., Kalinin A. A., Demidova T. B., Oleinichenko V. Yu., Aleksandrov D. Yu., Kouptzov A. V. Population ecology of red-toothed shrews, Sorex araneus, S. caecutiens, S. minutus, and S. isodon, in Central Russia. In: J. F. Merritt, S. Churchfield, R. Hutterer, B. I. Sheftel, eds. Advances in the Biology of Shrews II. New York, Special Publ. of the International Society of Shrew Biologists, 2005, pp. 201-216.

Shchipanov N. A., Alexandrov D. Yu., Alexandrova A. V. Dispersing of Spores of Micromycetes by Small Mammals. Zoologicheskii zhurnal, 2006, vol. 85, iss. 1, pp. 111-113 (in Russian).

Shekarova O. N. Conservation of Species Diversity and Conservation Status of Rodents (Order Rodentia). Pest Management, 2010, no. 3, pp. 32-35 (in Russian).

Shilov I. A. On the Mechanisms of Population Homeostasis in Animals. Uspekhi sovremennoi biologii, 1967, vol. 64, no. 2, pp. 333-351 (in Russian).

Shilov I. A. Ecologo-physiological Bases of Population Relationships in Animals. Moscow, Izdatel'stvo Moskovskogo universiteta, 1977. 261 p. (in Russian).

Shilova S. A. Population Ecology as a Base for Small Mammal control. Moscow, Nauka Publ., 1993. 201 p. (in Russian).

Shilova S. A. Abundance Control and Conservation of Sousliks in Russia (G. spermophilus). Arid Ecosystems, 2011 a, vol. 1, no. 4, pp. 267-272.

Shilova S. A. Current Problems in Rodent Pest Population Control and Biodiversity Conservation. Russian J. of Ecology, 2011 b, vol. 42, no. 2, pp. 165-169.

Shilova S. A., Tchabovsky A. V. Population Response of Rodents to Control With Rodenticides. Current Zoology, 2009, vol. 55, pp. 81-91.

Shilova S. A., Derviz N. V., Shilov I. A., Marova I. M., Pozhariiskii D. V. Some Features of the Territorial Distribution and Behavior of Midday Gerbils (Meriones meridianus, Rodentia, Cricetinae) Under Conditions Altered by Anthropogenic Impact. Zoologicheskii zhurnal, 1983, vol. 62, iss. 6, pp. 416-421 (in Russian).

Shilova S. A., Neronov V. V., Shekarova O. N., Savinetskaya L. E. Dynamics of Colonies of the Speckled Ground Squirrel (Spermophilus suslicus Guld., 1770) on the Northern Boundary of the Habitat. Biology Bulletin, 2010, vol. 37, no. 5, pp. 532-536.

Shilova S. A., Savinetskaya L. E., Neronov V. V. Dynamics of Population and Biomass of Little Souslik (Spermophilus pygmaeus Pall 1778) in Pasture Ecosystems of Kalmykia Over 28 Years. Arid Ecosystems, 2011, vol. 1, no. 3, pp. 177-183.

Shvarts S. S. Principles and Methors of Modern Animal Ecology. Trudy Instituta biologii UF AN SSSR, 1960, vol. 21, pp. 1-51 (in Russian).

Shvarts S. S. Population structure of species. Zoologicheskii Zhurnal, 1967, vol. 46, iss. 10, pp. 1345-1367 (in Russian).

Sih A., Bell A. M., Johnson J. C., Ziemba R. E. Behavioral Syndromes: An Integrative Overview. The Quarterly Review of Biology, 2004, vol. 79, no. 3, pp. 241-277. DOI: https://doi.org/10.1086/422893

Singleton G. R., Leirs H., Hinds L. A., Zhang Z. Ecologically-based management of rodent pests. Re-evaluating our approach to an old problem. In: G. R. Singleton, H. Leirs, L. A. Hinds, Z. Zhang, eds. Ecologically-based Management of Rodent Pests. Canberra, Australian Centre for International Agricultural Research, 1999, pp. 17-29.

Singleton G. R., Belmain S. R., Brown P. R., Aplin K. P., Htwe N. M. Impacts of rodent outbreaks on food security in Asia. Wildlife Research, 2010, vol. 37, no. 5, pp. 355-359. DOI: https://doi.org/10.1071/WR10084

Sluyter F., Van Oortmerssen G. A., De Ruiter A. J., Koolhaas J. M. Aggression in Wild House Mice: Current State of Affairs. Behavior Genetics, 1996, vol. 26, no. 5, pp. 489-496. 


\section{N. A. Shchipanov}

Sokolov V. E. Systematic of Mammals. Orders: Lagomorpha, Rodents. Moscow, Vysshaia Shkola Publ., 1977. 494 p. (in Russian).

Stanton J. C. Present-day Risk Assessment Would Have Predicted the Extinction of the Passenger Pigeon (Ectopistes migratorius). Biological Conservation, 2014, vol. 180, pp. 11-20.

Stearns S. C. The Evolution of History Traits. Annual Review of Ecology and Systematics, 1977, vol. 8, pp. 145-171.

Stearns S. C. The Evolution of Life Histories. Oxford, Oxford University Press, 1992. 262 p.

Sukachev V. N. Principal Concepts of Forest Biocenology. In: V. N. Sukachev, N. V. Dylis eds. Fundamentals of Forest Biogeocenology. Moscow, Nauka Publ., 1964, pp. 5-49 (in Russian).

Surkova E., Popov S., Tchabovsky A. Rodent Burrow Network Dynamics Under Humaninduced Landscape Transformation from Desert to Steppe in Kalmykian Rangelands. Integrative Zoology, 2019, vol. 14, iss. 4, pp. 410-420.

Surov A., Banaszek A., Bogomolov P., Feoktistova N., Monecke S. Dramatic Global Decrease in the Range and Reproduction Rate of the European Hamster Cricetus cricetus. Endangered Species Research, 2016, vol. 31, pp. 119-145.

Stenseth N. C., Demographic Strategies in Fluctuated Populations of Small Rodents. Oecologia (Berlin), 1978, vol. 33, pp. 149-172.

Stenseth N. C. On Chitty's Theory for Fluctuating Populations: the Importance of Genetic Polymorphism in the Generation of Regular Cycles. J. of Theoretical Biology, 1981, vol. 90, pp. 9-36.

Tchabovsky A. V., Savinetskaya L. E., Surkova E. N., Ovchinnikova N. L., Kshnyasev I. A. Delayed Threshold Response of a Rodent Population to Human-induced Landscape Change. Oecologia, 2016, vol. 182, pp. 1075-1082.

Tchabovsky A., Savinetskaya L., Surkova E. Breeding Versus Survival: Proximate Causes of Abrupt Population Decline Under Environmental Change in a Desert Rodent, the Midday Gerbil (Meriones meridianus). Integrative Zoology, 2019, vol. 14, iss. 4, pp. 366-375.

Turchin P. Does Population Ecology Have General Laws? OIKOS, 2001, vol. 94, pp. 17-26.

Van Oortmerssen G. A., Sluyter F. Studies on Wild House Mice. V. Aggression in Lines Selected for Attack Latency and Their y-chromosomal Congenics. Behavior Genetics, 1994, vol. 24, no. 1 , pp. 73-78.

Vernadsky V. I. Chemical Composition of Biosphere of Earth and Its Surroundings. Moscow, Nauka Publ., 1965. 348 p. (in Russian).

Vernadsky V. I. Biosphere. Moscow, Mysl' Publ., 1967. 261 p. (in Russian).

Virgós E., Cabezas-Dнaz S., Lozano J. Is the Wild Rabbit (Oryctolagus cuniculus) a Threatened Species in Spain? Sociological Constraints in the Conservation of Species. Biodiversity and Conservation, 2007, vol. 16, pp. 3489-3504. 
POPULATION RESILIENCE OF SMALL MAMMALS

УДК 599.323.42:574

\title{
ПОПУЛЯЦИОННАЯ УСТОЙЧИВОСТЬ МЕЛКИХ МЛЕКОПИТАЮЩИХ. ПОЧЕМУ ЭТО ВАЖНО И ОТ ЧЕГО ЭТО ЗАВИСИТ?
}

\author{
Н. А. Щипанов \\ Институт проблем экологии и эволючии им. А. Н. Северцова РАН \\ Россия, 117071, Москва, Ленинский просп., 33 \\ E-mail: shchipa@mail.ru
}

Поступила в редакцию 22.06.2019 г., после доработки 18.07.2019 г., принята 24.07.2019 г.

Shchipanov N. A. Population Resilience of Small Mammals. Why it is Important and What it Depends $\mathrm{On}$ ? [Щипанов H. A. Популяционная устойчивость мелких млекопитающих. Почему это важно и от чего это зависит?] // Поволжский экологический журнал. 2019. № 4. С. $503-523$. DOI: https: https://doi.org/10.35885/1684-7318-2019-4-503-523

Мелкие млекопитающие являются активным компонентом экосистем, которые поддерживают поток энергии и материи и которые отвечают как за строительство, так и за поддержание среды обитания. Такая деятельность жизненно важна для процветания человека, поскольку она поддерживает химическое и физическое качество среды, в которой человек приспособлен как биологический вид. Современная деятельность человека привела к разрушению ряда естественных мест обитания и, как следствие, к резким изменениям численности вида. Некоторые виды стали настолько многочисленными, что создают проблемы для здоровья человека, сельского хозяйства и промышленности. Некоторые ранее распространенные и даже вредные мелкие млекопитающие, напротив, сократились в распространении и численности и попали в категорию уязвимых видов. В обоих случаях экологически обоснованное управление популяциями необходимо для поддержания оптимальной численности видов. Эффективное экологически обоснованное управление популяциями может основываться на базовых принципах популяционной экологии. Это подразумевает понимание внешних и внутренних факторов, влияющих на численность населения. Здесь рассматриваются некоторые фундаментальные принципы, которые могут быть применены к оперативному управлению популяциями. Также автор останавливается на некоторых особенностях популяционных реакций, разработанных в российской экологической школе. Основываясь на хорошо известных принципах поддержки численности популяций, он предлагает классификацию видов с точки зрения их способности обеспечивать и изменять тип функции в локальных популяциях. Классификация позволяет выделить три группы видов с предсказуемой устойчивостью населения. Приспособленные к различной экологической нестабильности, виды этих групп требуют различной тактики сохранения.

Ключевые слова: мелкие млекопитающие, экологически обоснованное управление, численность населения, функции контроля и восстановления, типы функциональной структуры.

DOI: https://doi.org/10.35885/1684-7318-2019-4-503-523

Благодарности. Работа выполнена в рамках государственного задания Центра информационных технологий и систем «Экология и биоразнообразие наземных сообществ» (№ 0109-2018-0077) и при финансовой поддержке Российского фонда фундаментальных исследований (проект № 19-04-00985). 